\title{
NORWEGIAN YOUTH PUNISHMENT - OPPORTUNITY OR TRAP?
}

\author{
MORTEN HOLMBOE*
}

\section{Introduction}

In Norway, the age of criminal responsibility is 15 years. ${ }^{1}$ There is a long tradition in Norwegian law for treating young offenders less severely than mature offenders. This is, of course, not unique to Norwegian society. ${ }^{2}$ However, in this article, I focus on some specific Norwegian regulations concerning (the choice of) penal reaction towards young offenders. I especially focus on the recently established system of youth punishment.

In Norwegian law and jurisprudence, there is a sharp line drawn between the treatment of 17-year-olds and 18-year-olds. While the punishment for an offender of age 17 years 11 months will often be significantly more lenient, an offender who just turned 18 will seldom receive a more lenient sentence because of his or her age. Offenders under the age of 18 at the time of the offence are thus subject to a more lenient approach in that they

Associate Professor, The Norwegian Police University College.

1 The Norwegian Criminal Code, Act 2005-05-20-28 (Lov om straff), section 20, subparagraph a. For an overview in English, see Jacobsen and Sandvik, An outline of the new Norwegian criminal code, 3 Bergen Journal of Criminal Law and Criminal Justice (2015) pp. 162-183. For an overview in German (with a German translation of the Code), see Cornils and Husabø, Das norwegische Strafgesetz: vom 20. Mai 2005 nach dem Stand vom 1. Juni 2014 = Lov om straff: (straffeloven) (Duncker \& Humblot 2014).

2 For a Nordic overview, see Lappi-Seppälä, Nordic youth justice in Crime and justice in Scandinavia, eds. Tonry and Lappi-Seppälä (The University of Chicago Press 2011) pp. 199-264; Lappi-Seppälä and Storgaard, Unge i det strafferetlige system, 14 Tidsskrift for strafferett (2014) pp. 333-359. For a comparative approach to the Swedish and German juvenile legal systems, see Persson, Caught in the middle?: Young offenders in the Swedish and German criminal justice systems (Lund University 2017).

This is an Open-access article distributed under the terms of the Creative Commons Attribution 3.0 Unported License (http://creativecommons.org/licenses/ by/3.0/), permitting all use, distribution, and reproduction in any medium, provided the original work is properly cited. 
are only sentenced to prison as a last resort, and as the prison sentence may not exceed 15 years. ${ }^{3}$

When a young person is sentenced to prison, the correctional services (kriminalomsorgen) will especially focus on the needs of the young offender during the serving of the prison sentence. There are two special prisons for young offenders, one on the west coast near Bergen (Bjørgvin) and one in the eastern part of the country (Eidsvoll).

In 2014, Norway implemented two new kinds of reactions for young offenders: youth punishment (ungdomsstraff) and youth follow-up (ungdomsoppfølging). These reactions are intended to build upon the ideas of restorative justice. ${ }^{4}$ The relationship between the criminal justice system and the ideas behind restorative justice is not always an easy one. It seems that a positive attitude towards restorative justice is more easily adopted at scholarly conferences than in courtrooms. There are few cases in the jurisprudence of the Supreme Court where the ideas behind restorative justice lead to a milder sentence. In Norwegian criminal doctrine, discussion on restorative justice was rather uncommon until just a few years ago. ${ }^{5}$

Nevertheless, in the newly adopted Mediation Services Act, restorative justice (gjenopprettende prosess) has been stated as a principle. Now, it is also stated in the Execution of Sentences Act that the correctional services shall offer restorative justice during the execution of the punishment. ${ }^{6}$ The youth follow-up may be applied after a decision is made by a prosecutor ${ }^{7}$ or a court. ${ }^{8}$ The duration of the period of follow-up may not exceed one year. The youth punishment may only be determined by a court. The

The Criminal Code, section 33.

See Gröning and Jacobsen, Introduction: Restorative justice and the criminal justice system in Restorative justice and criminal justice: Exploring the relationship, eds. Gröning and Jacobsen (Santérus 2012) pp. 9-19; Fornes, Restorative justice in the Norwegian juvenile justice system, ibid. pp. 93-121; Paus, Restorative Justice in Norway, Values and Practices at a Crossroad/Justicia restaurativa - valores, metas y retos in Restorative processes from Oslo to Havana and back: Discussions on implementing and strengthening restorative justice processes in Cuba and Norway/Los procesos restaurativos en Oslo y la Habana: Experiencas y diálogos teóricos acerca de la justicia restaurativa en Cuba y Noruega, eds. Nafstad and Papendorf (Novus 2017) pp. 23-56 and 23-58.

5 See Holmboe, Fengsel eller frihet: Om teori og praksis i norsk straffutmåling, scerlig $i$ grenselandet mellom fengsel og mildere reaksjoner (Gyldendal 2016) pp. $62-65$ (hereafter Holmboe 2016a).

6 See the Act 2014-06-23-49 on the Mediation Services (Lov om konfliktrådsbehandling (konfliktrådsloven)), section 1 and Act 2001-05-18-21 relating to the execution of sentences etc. (The Execution of Sentences Act), (Lov om gjennomføring av straff mv. (straffegjennomføringsloven)) section 2.

7 See The Criminal Procedure Act 1981-05-22-25 (Lov om rettergangsmåten i straffesaker (Straffeprosessloven)), sections 69 and 71a.

$8 \quad$ The Criminal Code, section 37, subparagraph $j$. 
execution period shall be from six months to two years, and in exceptional cases, three years. ${ }^{9}$

For both reactions, the defendant (and his or her legal guardian) has to consent if the reaction is to be imposed. As the youth reactions are intended to be the most suitable for the young offender, the defendant thus has an opportunity to receive a form of punishment that is constructive and restorative. However, the consent is given before the reaction is meted out. The content of the reaction is decided later, in a youth conference. Thus, the opportunity may become a trap if the content of the reaction turns out to be more severe than the punishment that would have been chosen instead of a youth reaction.

Although the two youth reactions are similar on many counts, the youth punishment is reserved for more serious offences, and the repercussions for an offender failing to meet the conditions in the action plan may be more severe than when the reaction is youth follow-up. If an offender sentenced to youth punishment does not meet the conditions, he or she risks imprisonment. In this article, I therefore focus on youth punishment.

\section{Youth Punishment: A General Overview of the Process}

The process of determining the penal reaction is divided. The court stipulates for how long the youth punishment is to be carried out, and how long the prison sentence shall be if the offender commits new criminal offences, if a youth action plan is not reached or if the obligations in the plan are not met. The process of determining youth punishment following sentencing is divided into three stages: (i) the arranging of a youth conference (ungdomsstormøte), (ii) the making of an action plan (ungdomsplan), and (iii) the carrying out of the action plan (oppfølging av planen).${ }^{10}$ In the youth conference, an action plan is decided, and a follow-up team co-operates with the offender to fulfil the plan. If the defendant does not agree to the sentencing to youth punishment, the court has to choose another form of punishment. If the offender does not fulfil the obligations in the action plan, or commits new offences, the case may be sent back to the court, where it decides if the alternative prison sentence shall be executed.

$9 \quad$ The Criminal Code, Chapter 8 a.

10 See the Act on the Mediation Service, section 22. 
The process may seem a bit intricate. An overview is shown here.

\section{Figure 1: Overview of the process}

\begin{tabular}{|c|c|c|c|c|}
\hline Crime -> Investigation - & $\begin{array}{l}\text { Court -> } \\
\text { hearing }\end{array}$ & 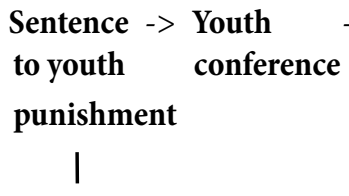 & $\begin{array}{cc}->\text { Action } & -> \\
\text { plan } & \begin{array}{c}\text { Follow-up } \\
\text { of the action }\end{array} \\
& \text { plan }\end{array}$ & $\begin{array}{l}->\text { Action } \\
\text { plan } \\
\text { fulfilled }\end{array}$ \\
\hline $\begin{array}{l}\text { Social inquiry } \\
\text { for minors }\end{array}$ & $\begin{array}{l}\text { Offender } \\
\text { (and } \\
\text { guardian) } \\
\text { consents to } \\
\text { youth } \\
\text { punishment }\end{array}$ & $\begin{array}{l}\text { Alternative } \\
\text { prison sentence }\end{array}$ & $\begin{array}{l}\text { Offender } \\
\text { (and } \\
\text { guardian) } \\
\text { consents to the } \\
\text { action plan }\end{array}$ & \\
\hline
\end{tabular}

Period of execution

Certain specific procedural requirements apply in cases concerning youths. When it is deemed to be of significance for deciding on a penalty or other precautions, a social inquiry relating to the person charged shall normally be carried out. As a main rule, such a social inquiry regarding a person less than 18 years of age at the time of the crime shall be carried out unless it is clear that it will be unnecessary. ${ }^{11}$ For instance, it will be unnecessary if a social inquiry for minors has recently been carried out.

If a suspected person was under 18 years of age at the time the crime was committed, the question of preferring an indictment shall be decided not later than six weeks after the defendant is deemed a suspect in the case. The prosecuting authority may, however, decide the question of indictment later 'if due regard for the investigation or other special reasons so necessitate..$^{12}$ Such a reason may be that the finishing of social inquiries for minors has taken longer than expected due to the resources of the correctional services. Therefore, the Director of Public Prosecutions (Riksadvokaten) has amended the guidelines to pursue a faster handling of cases. ${ }^{13}$

When the accused was under 18 years of age at the time of the crime, the right to a defence counsel (paid for by the state) is extended. He or she shall always have a

The Criminal Procedure Act, section 161 a. Such a social inquiry is called social inquiry for minors (personundersøkelse for mindreårige, often abbreviated PUM).

12 The Criminal Procedure Act, section 249.

13 Riksadvokaten, Justerte retningslinjer for innhenting av personundersøkelse for mindreårige lovbrytere, 2015. See Eide et al., Stemmer «kartet» med «terrenget»?: Underveisrapport fra en følgeevaluering av ungdomsstraff og ungdomsoppfølging (Nordlandsforskning 2016) pp. 33-35. 
defence counsel if the case may lead to a community sentence, a youth punishment or an unconditional prison sentence. ${ }^{14}$

\section{Youth Punishment as an Alternative to Imprisonment}

According to the UN Convention on the Rights of the Child (CRC) art. 37 subparagraph $\mathrm{b}$, the 'imprisonment of a child shall be in conformity with the law and shall be used only as a measure of last resort and for the shortest appropriate period of time'. In Norwegian law, as in the CRC art. 1, a child is a person below the age of 18 years. The youth punishment is intended to make it possible to reduce the use of prison sentence towards children and thus to strengthen the use of imprisonment as a 'measure of last resort'.

The youth punishment is intended to be used instead of prison sentence for rather serious offences committed by young offenders. However, the use of imprisonment for young offenders is not abolished. In cases of murder or serious sexual offences, for example, inprisonment will still, as the clear main rule, be deemed to be the proper punishment. ${ }^{15}$ I will return to this below.

In many cases, the courts have meted out community sentences (samfunnsstraff), especially to young offenders. Youth punishment is considered a more severe form of punishment than a community sentence, and may be meted out instead of the longest community sentences. Nevertheless, a community sentence may be combined with imprisonment for up to sixty days. In certain cases, an offender would probably deem a long community sentence combined with a prison sentence as a more severe form of punishment than a youth punishment.

The different forms of punishment may be shown thus (from the most severe to the most lenient):

- Imprisonment

- Youth punishment

- Community sentence

- Conditional imprisonment (suspended sentence)

Most forms of punishment may be combined with other sorts of punishment. A suspended sentence may be only partly suspended, so that the offender will have to serve at least some time in prison. A community sentence may be combined with imprisonment

The Criminal Procedure Act, section 96.

On the use of restorative justice as an alternative or supplement to the traditional criminal justice system in cases of sexual crime, see Joyce-Wojtas and Keenan, Is restorative justice for sexual crime compatible with various criminal justice systems?, 19 Contemporary Justice Review (2016) pp. 43-68. 
up to 60 days. Both a prison sentence and a community sentence may also be combined with a fine. ${ }^{16}$ Youth punishment, however, may not be combined with any other kind of punishment. The reason is that youth punishment is designed to keep offenders out of prison, and the legislator has therefore not allowed the youth punishment to be combined with a prison sentence. ${ }^{17}$ This may, however, lead to certain problems when the offender is tried for crimes committed both before and after turning 18 years of age. ${ }^{18}$

\section{When Can the Court Sentence an Offender to Youth Punishment?}

\subsection{The Conditions for Youth Punishment - Overview}

Several conditions must be fulfilled for the court to be able to sentence the defendant to youth punishment. The offender must be under 18 years of age at the time of the crime (a), he or she must consent to the sentence of youth punishment (b) and be resident in Norway (c), and the offence must be serious or repeated (d). Finally, the use of youth punishment must not be contradictory to the purposes of punishment (e).

\subsection{The Offender Must Be Under 18 Years of Age at the Time of the Crime}

The most basic condition is that the offender must have been under 18 years of age at the time of the crime. There is no statutory age limit for how old a person can be when sentenced to youth punishment. The Criminal Code, section 33 (prison as the last resort) applies as long as the offender was less than 18 years old at the time of the crime, even if the offender is far older at the time of the trial. Nevertheless, should a serious crime be brought before the courts many years after the defendant was no longer a minor, a youth punishment would probably not be advisable. In such a case, a solution could be to sentence the defendant to community sentence instead. In a special case, the Supreme Court meted out a suspended sentence for a serious sexual offence where the offender was 16 years old at the time of the crime, which was committed ten years before the trial. ${ }^{19}$

A practical problem may arise if the defendant is tried for more than one crime, and at least one of the crimes was committed after he or she turned 18 years old. It is, as stated earlier, not permitted to combine a youth punishment with another kind of punishment.

The Criminal Code, sections 32 and 51.

Prop. 135 L (2010-2011) pp. 166-167 (preparatory work).

See para. 7, c below.

The Supreme Court's judgement 15 December 2004, Rt. 2004 p. 1949. The case is described later in the article. 
If a minor commits a crime, which in itself should be punished with a youth punishment, but then commits another crime after turning 18 years of age, what shall the court choose?

One option is to sentence the defendant to community sentence or imprisonment, and take into consideration that he or she was a minor when committing the first crime(s). Another option is to sentence the defendant to youth punishment and take into consideration the crime(s) committed after the defendant turned 18 years of age.

The solution will probably depend on the degree of seriousness of the crimes committed after the defendant turned 18 years old.

Such a case was decided by the Norwegian Supreme Court (Høyesterett) earlier this year. ${ }^{20}$ The defendant had been found guilty of sexual intercourse with a minor (a girl of 13 years eight months) when he was himself 17 years nine months. In addition, while a minor, he illegally acquired a credit card in another person's name. After he turned 18 , the offender used the card to obtain goods ordered in the other person's name (fraud). ${ }^{21}$ The Supreme Court decided that this crime of fraud committed after the defendant turned 18 was not serious enough to bar the use of youth punishment for the sexual offence committed while he was a minor. The court did not, however, provide any guidelines as to how serious the new crime could be. ${ }^{22}$

One option is thereby to compare the crime committed that in itself would lead to a youth punishment to the crime committed after the defendant turned 18 years of age. If the court decides that youth punishment is a reasonable punishment for the former crime, and the new crime is less serious, that could be a good reason for choosing youth punishment. In the case referred to above, this seems to have been the court's reasoning. In the Court of Appeal, the defendant had been sentenced to prison for three years, out of which two years were a suspended sentence. The new crime committed after the defendant turned 18 would not lead to a long prison sentence. If the court had found youth punishment to be impermissible and felt obliged to choose prison as the punishment, the new crime would have had big repercussions: a crime that would normally carry maybe a month or two in prison would have lead to imprisonment for a year. The defendant would also lose the possibility to take part in the restorative processes inherent in a youth punishment. in the article.

21 The former Criminal Code 1902, section 270 (bedrageri). See the Criminal Code (2005), section 371.

22 See Guidelines from the Director of Public Prosecutions (Riksadvokaten), August 2017: "Ungdomsstraff - oppdaterte retningslinjer". <http://www.riksadvokaten.no/no/dokumenter/ retningslinjer/Justerte+retningslinjer+om+ungdomsstraff.b7C_wlbOXL.ips $>$ [Accessed 28 September 2017]. 
One problem with such an approach, however, is that the former crime can lead to a milder punishment than if the defendant had committed only one crime after turning 18. In such a case, a practical approach could be to mete out the punishment as a community sentence. Such sanctions may, as stated above, be combined with prison for up to 60 days, or with a fine. Thus, the court would be free to apply a milder sanction for the crime committed while the defendant was under 18 , as well as a reasonable punishment for the crime committed when he or she had turned 18.

\subsection{The Defendant's Consent}

A youth punishment is to be carried out in close co-operation between the Mediation Services, other services and the convicted young person. Therefore, the defendant has to consent in order for the court to be able to sentence him or her to youth punishment. If he or she is still a minor when the sentence is passed, the guardian also has to consent. (The defendant's consent is also required for an action plan to be made; see point 5 below.)

The defendant's consent to youth punishment does not necessarily imply a confession to the crime. Such an obligation could carry a risk for untrue confessions. Recent research implies that innocent people risking a severe punishment may confess to the charge if such a confession reduces the punishment significantly. ${ }^{23}$ As the alternative to a youth punishment may be imprisonment for a rather long time, it could be hazardous to demand a confession for the court to be able to mete out youth punishment. Nevertheless, the defendant has to accept the facts of the judgement if he or she meets with the victim as part of the youth meeting.

\subsection{The Defendant Must Be Resident in Norway}

The carrying out of a youth punishment will require that the defendant is available for the Mediation Services. He or she is obliged to stay within Norway during the carrying out of the youth punishment. Therefore, the law requires that the defendant must be a resident in Norway. This does not require him or her to be a Norwegian citizen, but he or she must have legal residence here.

23 See Dervan and Edkins, The Innocent Defendant's Dilemma: An Innovative Empirical Study of Plea Bargaining's Innocence Problem, 103 Journal of Criminal Law and Criminology (2013) pp. $1-48$. 
A similar condition is set for a community sentence, but will probably be amended in order to give citizens from other Nordic countries the opportunity to serve the community sentence in their home country. ${ }^{24}$

Thus, when a young offender who is a resident in Norway is convicted of a serious crime, the court can choose between:

- a suspended prison sentence

- community sentence

- youth punishment

- imprisonment

When a young offender is sentenced for rather serious crimes, the sentence will often be a community sentence or a youth punishment: the suspended prison sentence may be found too lenient, and the imprisonment too harsh. But what is to be done when the court cannot resort to the two middle options?

If an offender resident in Norway would be given a community sentence or youth punishment, handing down a more lenient, suspended prison sentence to an offender who lives abroad would be difficult. However, it is also difficult to accept that if two offenders are guilty of the same crime, the Norwegian resident would be treated mildly (with a community sentence or youth punishment) whereas the foreign resident would be imprisoned. Admittedly, the possibility for rehabilitating the offender may be greater if he or she resides in Norway. However, the current law raises difficult questions concerning the CRC art. 2, forbidding 'discrimination of any kind. ${ }^{25}$ When the rules concerning community sentence are amended, it will be possible to solve this problem for defendants residing in other Nordic countries, but (still) not for those residing in other countries. samfunnsstraff-mellom-de-nordiske-land/id2517186/> [Accessed 28 September 2017]. See the UN Committee on the Rights of the Child, General Comment No. 10 (2007), para. 6; Holmboe, Ungdomsstraff og ungdomsoppfølging: En oversikt og noen kritiske merknader, 14 Tidsskrift for strafferett (2014) pp. 397-414, at 405-407. On the interpretation of the General Comments of the Committee, see Bårdsen, Children's Rights in Norwegian Courts, 2015, http://www.domstol.no/globalassets/upload/hret/ artikler-og-foredrag/childrens-rights-in-norwegian-courts---kathmandu-250615.pdf [Accessed 28 September 2017]. 


\subsection{The Offender Must Have Committed Serious or Repeated Criminal Offences}

Youth punishment is supposed to be used for serious cases. A case is deemed to be serious if it could carry imprisonment for three years or more according to the law. ${ }^{26}$ It is not required that the actual punishment be so severe, only that the law provides the court with such an option.

Examples (in the Criminal Code) of offences with an upper limit of three years' imprisonment are violence or threats against a public servant (section 155; vold eller trusler mot offentlig tjenestemann), aggravated carrying of firearms in a public place (section 189 a; grov ulovlig bevcpning med skytevåpen på offentlig sted), serious threats against a person (section 264; grove trusler) and counterfeiting of money (section 367; pengefalsk). Crimes of an even more serious nature are, e.g., robbery (section 327; ran), aggravated obtaining of the proceeds of a criminal act (section 333; grovt heleri), aggravated violence (section 272; grov kroppskrenkelse) and several sexual offences (seksuallovbrudd). In principle, the reaction is also available for the most serious offences such as murder and even terrorist offences. However, the criteria described below will, as we shall see, normally bar the use of youth punishment.

If the offender has committed repeated criminal offences, it is not necessary that each of them is serious. However, even repeated offences can hardly give reason for sentencing the defendant to youth punishment if they are mere trifles.

\subsection{The Use of Youth Punishment Must Not Be Contradictory to the Purposes of} Punishment

Youth punishment is intended to be used for rather serious crimes, and the law provides as said no absolute upper limit as long as the offender was less than 18 years of age at the time the crime was committed. Nevertheless, youth punishment is not - as the clear main rule - supposed to be used for murder or for serious sexual offences. Normally, youth punishment would be considered to contradict the aim of general deterrence and the public's sense of justice. The Supreme Court has held, though, that there are cases where even serious sexual offences may be punished with youth punishment. ${ }^{27}$

After youth punishment was introduced in Norwegian law, the courts have decided on the question of youth punishment in several cases. In most cases, the prosecution and the defence have agreed that youth punishment is the proper reaction. However, in Norwegian criminal procedure, the court is not bound by this, and can mete out a

26 Prop. 135 L (2010-2011) p. 164 (preparatory work).

27 Prop. 135 L (2010-2011) p. 115 (preparatory work); the Supreme Court's judgement of 23 June 2016, HR-2016-1364-A. 
more severe punishment than the prosecutor recommends. Nevertheless, the court will usually be reluctant to mete out a more severe punishment, as exemplified by Frostating Court of Appeal's judgement of 1 July 2016, where a 17-year-old man was convicted for aiding and abetting rape. The court's majority (four judges), on the recommendation of the prosecutor, sentenced the defendant to youth punishment with the maximum execution period of three years, and an alternative prison sentence of four years. The minority (three judges) voted for a prison sentence because of the nature of the crime. ${ }^{28}$

Young offenders have been treated less severely than adults for a long time. Even in cases of serious sexual offences, some young offenders have been punished with a suspended sentence or with a community sentence instead of prison. Some examples: In 2003, a 15-year-old girl was convicted of aiding and abetting rape against a girl of the same age. She was sentenced to 300 hours of community sentence, with an execution period of $1 \frac{1}{2}$ year and an alternative prison sentence of 10 months. ${ }^{29}$ In 2004, a boy of 17 years of age was sentenced for sexual activity with a seven-year-old girl. The Court of Appeal had sentenced him to community sentence for 240 hours, with a period of execution of eight months and an alternative prison sentence of eight months. The Supreme Court (a majority of three judges) held that there was not sufficient reason to overturn the sentence of the Court of Appeal, and upheld the sentence. A minority (two judges) held that the punishment should be prison for eight months, with 90 days' imprisonment and the rest of the punishment as a suspended sentence. ${ }^{30}$ In the same year, a boy of 16 years at the time of the crime was sentenced to prison for nine months for having had intercourse with his nine-years-old sister. The sentence was suspended because the crime had happened ten years earlier, and because the defendant suffered from personal difficulties. ${ }^{31}$ In 2009 , a boy of 16-17 years was convicted for having had intercourse with a girl of 10-11 years. He had himself been a victim of sexual offences. Because of the crimes, he had been subject to placement and retention in an institution without his own consent. This retention had turned out well, and the Supreme Court meted out a punishment of one year and eight months' suspended prison sentence. ${ }^{32}$

As can be seen, the Norwegian courts have been reluctant to sentence young offenders to imprisonment for a long time, also before the youth punishment was introduced in 2014. Nearly two years went by before the Supreme Court decided on the use of youth punishment in serious cases. At the time of writing (September 2017), the Supreme Court has decided three cases concerning youth punishment.

29 The Supreme Court's judgement of 14 October 2003, Rt. 2003 p. 1455.

$30 \quad$ The Supreme Court's judgement of 24 February 2004, Rt. 2004 p. 327.

31 The Supreme Court's judgement of 15 December 2004, Rt. 2004 p. 1949.

32 The Supreme Court's judgement of 13 March 2009, Rt. 2009 p. 327. 
In 2016, the Court decided two cases on the same day. In the first case, two defendants had committed aggravated rape against a 14-year-old boy. They were also found guilty of sexual intercourse with a minor committed in a particularly painful or offensive manner, for filming the sexual abuse of the victim, for violence committed under especially aggravating circumstances and for sexually indecent behaviour towards a child under 16 years of age.

The defendants were, respectively, 15 years eight months and 16 years two months. The rape was aggravated because the offenders were committing the crime together and the victim was subjected to degrading acts. As the victim was only 14 years old, the rape was also a violation of the Criminal Code's prohibition against sexual activity against a child between 14 and 16 years of age. (If two young people engage in voluntary sexual activity and they are about equal as regards age and development, the penalty may be remitted. ${ }^{33}$ But this will not apply when the minor is forced into the sexual activity. ${ }^{34}$ )

Both the offenders and the victim were pupils in a school for children who had special challenges in the school system. The District Court found the defendants guilty. After considering the question of punishment carefully, the court sentenced both defendants to youth punishment for $2 \frac{1}{2}$ years, with an alternative prison sentence of $2 \frac{1 / 2}{2}$ years. The court noted that the crimes were very serious. Still, the court reasoned that the defendants had special needs that would probably become worse if they had to serve prison time.

The prosecutor appealed the sentence and held that the crimes were so serious that the punishment should be prison. The Court of Appeal agreed, and both defendants were sentenced to prison. The prison terms were set to four years, with two years as a suspended sentence. The defendants appealed to the Supreme Court, which agreed with the Court of Appeal that the crimes were too serious for youth punishment to be applicable. The unconditional parts of the prison sentences were, however, reduced to one year.

The Supreme Court held that even if the main rule concerning young offenders is that prison shall only be used as a last resort, certain cases - murder and serious sexual offences - are so aggravating that the point of departure, even for a young offender, will be prison. The facts of the case still have to be considered, but the personal situation of the defendants was not a sufficient reason for a more lenient sentence.

On the same day, the Supreme Court decided another case where the offender held that he should be sentenced to youth punishment instead of prison. He had engaged in repeated sexual activity against a small girl. The offender was 15 to 16 years of age during the period of about a year when the crimes were committed. The girl was five to six years old. The crimes had been repeated and were of a serious nature. The Supreme Court referred to its judgement of the same day and upheld the punishment of $3 \frac{1 / 2}{2}$ years

33 The Criminal Code, section 308.

34 The Supreme Court's judgement of 5 February 2016, HR-2016-287-A, para. 24. 
imprisonment, out of which eight months should be served in prison; the remainder was a suspended sentence. ${ }^{35}$

These two cases did not provide a clear guideline for when youth punishment may be used instead of prison in cases of serious offences, but showed that there are crimes so serious that prison may be considered as the proper punishment even for offenders less than 16 years of age - also for those with special needs. The question therefore remained as to whether youth punishment could be used for sexual offences that were not as aggravating as in the cases decided in 2016.

In 2017, the Supreme Court decided one case where the issue was whether the defendant should be sentenced to youth punishment or imprisonment. The defendant was a boy of 17 years nine months who had had intercourse several times with a girl of 13 years eight months. (Under Norwegian law, engaging in intercourse with a child who is under 14 years of age is considered a serious offence. For an offender who has turned 18 years old at the time of the crime, the law states that the punishment shall be imprisonment between 3 and 15 years, normally four years.) The District Court sentenced the offender to youth punishment. The Court of Appeal sentenced him to prison for three years, out of which two years were suspended. The Supreme Court changed the sentence to youth punishment for two years, with an alternative prison sentence of two years. The Court held that this sexual offence was not nearly as serious as the cases decided in 2016. The crime was a serious one, but the age difference between the parties was not exorbitant. If the defendant had been slightly younger, the punishment might have been remitted. ${ }^{36}$

The latest judgement shows that even a sexual offence that is generally considered serious in nature, does not bar the courts from sentencing a young offender to youth punishment. As can be seen from the earlier cases from the Supreme Court, cited above, this judgement does not radically change the jurisprudence of the Court concerning the use of milder reactions towards young offenders, not even in cases of serious sexual offences.

The Supreme Court's judgements so far show that for the most serious offences, youth punishment cannot be used instead of prison. Nevertheless, the earlier judgements about community sentence show that the threshold for sentencing young offenders to imprisonment was quite high even before the youth punishment was introduced. The threshold may have become slightly higher with the introduction of youth punishment. But the introduction of youth punishment has, in my opinion, not lead to a big change in the courts' choice of penal reaction. Whether we will see a further development in the direction of substituting youth punishment for imprisonment, may depend on how successful the reaction is deemed to be after some more time has gone by. Possibly, the 
courts would be even more open to choosing youth punishment if they were allowed to decide more about the content of the punishment, not just the duration of the execution period.

\section{The Making and Follow-up of the Action Plan}

\subsection{The Process of the Action Plan - Overview}

While the execution of sentences is normally done through the correctional services, the execution of a youth punishment (and a youth follow-up) is done by the Mediation Services (konfliktrådet). The reason is that these reactions are inspired by the idea of restorative justice, and the youth conference (see below) may include a meeting between the offender and the victim. ${ }^{37}$

When the court has sentenced an offender to youth punishment, the case is forwarded to the Mediation Services. The reaction consists of a youth conference (ungdomsstormøte), the making of an action plan (ungdomsplan) and following up the plan (oppfølging av planen). ${ }^{38}$ After the sentence has been passed and the judgement is final, the case is referred to the Mediation Services. A youth co-ordinator (ungdomskoordinator) arranges a youth conference.

\subsection{The Youth Conference}

The youth conference is chaired by a youth co-ordinator. ${ }^{39}$ The idea behind this conference is that the relevant authorities shall co-operate in making a co-ordinated action plan. The offender must attend the youth conference. He or she has a right to bring a defence counsel, as the content of the action plan is what determines the content of the punishment. His or her guardian shall also attend.

The victim is under no obligation to attend the conference, but has a right to attend if he or she so chooses. The victim's guardian also has a right to attend. If the victim so chooses, there shall be a meeting between the offender and the victim where they can talk through what happened. It is also possible to reach an agreement, e.g. that the

\footnotetext{
37 For a criticism of this extension of the powers of the Mediation Services, see Christie, Widening the net, 3 Restorative Justice: An International Journal (2015) pp. 109-113. See also Paus 2017. - For a defence of this extension, see (the then Director of the Mediation Services) Andersen, Lay mediators in the future, 3 Restorative Justice (2015) pp. 114-118.

38 The Mediation Services Act, section 22.

39 See the Mediation Services Act, section 24.
} 
offender shall give non-pecuniary compensation to the victim, such as practical help, etc. (Compensation for the damage done to the victim will normally be decided in the judgement by the court.) The parties may also agree that the offender shall not make contact with the victim. Such agreements can be taken into the action plan. The offender may deny in court that he or she is guilty and still be sentenced to youth punishment, but in the youth conference, he or she must accept the facts that have been proved in court. ${ }^{40}$

Thus, the judge may decide that the case shall be referred from the criminal justice system to a system built on restorative justice. Originally, the restorative justice movement was an alternative to the traditional criminal justice system, whereas it is now co-opted into the system. This combination of restorative justice and the criminal justice system poses some problems. It may be questioned whether the victim can trust an apology given when the offender has to 'accept responsibility' in order to avoid a long prison sentence. As stated by Murphy: 'The cynicism spawned in our "culture of apology" - where apologies automatically appear on the lips of people trying to avoid responsibility - may have undercut to a substantial degree the social value of the apology ritual. ${ }^{41}$

The youth co-ordinator shall see to it that all relevant actors are represented in the youth conference. Examples are representatives of the school, the child welfare services, the health and social services as well as other bodies connected to the offender or the victim.

At first glance, it may seem odd that the welfare services are obliged to meet to coordinate the services for an offender. But it is not as if the offender gets a better legal standing by committing an offence. It is a vital part of the Norwegian system that an offender does not lose his or her rights as a citizen. Thus, the youth conference serves as an opportunity to co-ordinate services that should work together anyway. - This principle of 'normality' applies also in the other forms of execution of punishment that are the responsibility of the correctional services. ${ }^{42}$

In cases concerning youth punishment, the police and the correctional services shall always take part in the conference. (In cases concerning the less severe reaction of youth follow-up, the participation of the police and the correctional services is not mandatory, but they will often attend.) Not only public bodies, but also relevant NGOs or concerned

See the remarks given by the Supreme Court in its judgement HR-2016-1364-A, para. 29 to 30.

Murphy, Punishment and the moral emotions: essays in law, morality, and religion (Oxford University Press 2012) p. 177. See also Van Stokkom, Book review: Jeffrie G. Murphy, Punishment and the moral emotions: essays in law, morality, and religion, 1 Restorative Justice (2013) pp. 150-153, at 152; and Holmboe 2016a p. 111.

See the Execution of Sentences Act, section 4; cf. Vollan, 'Mot normalt'?: Normalitetsprinsippet i norsk straffegjennomføring, 16 Tidsskrift for strafferett (2016) pp. 447-461. (Original: 'Mot normalt'?: Normalitetsprinsippet i norsk straffegjennomføring in Lov, liv og loere: Festskrift til Inge Lorange Backer, eds. Bugge et al. (Universitetsforlaget 2016) pp. 548-560). 
private citizens may take part in the youth conference if the offender so chooses. All participants in the youth conference have a legal obligation to keep personal information confidential. ${ }^{43}$

\subsection{The Action Plan}

The action plan (ungdomsplan) is discussed and decided in the youth conference. ${ }^{44}$ It has to be accepted by the offender and his or her guardian. It also has to be signed by the youth co-ordinator. As mentioned earlier, the victim has the right to attend the youth conference. However, the victim shall not sign or agree to the action plan. Even though several other public servants, etc. may attend the youth conference, there are no rules in the law stating who has to accept the plan. This must mean that the youth co-ordinator may agree to an action plan that other participants disagree with. ${ }^{45}$

The offender may, of course, decline to accept a suggested action plan because he or she disagrees with a certain measure in the plan. If the youth co-ordinator holds that this measure is necessary and the offender still declines, the case will be returned to the court. The court then decides whether the alternative prison sentence shall be wholly or partly executed.

As youth punishment will be meted out in rather serious cases, the alternative prison sentence will normally be long. If it is not possible to agree on an action plan, the offender thus risks serving a long time in prison. This means that an offender who disagrees with a proposed condition in the action plan will be under heavy pressure to accept the measure.

The action plan may contain several different kinds of conditions. While the judgement by the court will normally be available to the public, the action plan will be confidential. The plan will, however, be what really determines the kind and severity of the punishment allotted in a specific case. ${ }^{46}$ The regulation states that the list of possible measures is not exhaustive: the list is introduced with the words inter alia ('blant annet'). Thus, it is difficult to prepare the offender for what kinds of measures that may be included in the action plan. ${ }^{47}$

$43 \quad$ The Mediation Services Act, section 9.

44 See The Mediation Services Act, section 25. This plan is sometimes called 'youth plan' or 'youth action plan', see Andersen 2015 p. 116.

$45 \quad$ See Holmboe, Konfliktrådsloven med kommentarer (Universitetsforlaget 2016) pp. 129134 (hereafter Holmboe 2016b).

46 See Eide et al. 2016; Fornes, Ungdomsstraffens første år: En undersøkelse av ungdomsstraffens anvendelsesområde og innhold i straffartens første år, 16 Tidsskrift for strafferett (2016) pp. 238-280.

47 See Holmboe, Reelt og informert samtykke til ungdomsstraff og ungdomsoppfølging, 16 Tidsskrift for strafferett (2016) pp. 215-237. 
The possible measures in the action plan may be sorted into four groups: ${ }^{8}$ Some of them will be meant to equip the offender for a crime-free life in society, e.g. going to school or work, taking part in programmes to prevent new crime,${ }^{49}$ or moving to an institution, e.g. under the child welfare services. Some actions will be restorative, as in giving nonpecuniary compensation to the victim, or as the offender promises to avoid contact with certain persons. The latter clause may be to avoid contact with the victim, or with friends who may be a bad influence.

It is also important to control that the offender fulfils his or her obligations and does not commit new crimes. It can be decided in the action plan that the offender has to meet regularly with the police or the correctional services. Such meetings with the police may also be about more than controlling the offender. In some cases, the police also schedule talks with the offender about how to change behaviour concerning criminal actions, using of drugs, etc. Thus, they may appropriately also be labelled as equipping the offender for a law-abiding life. ${ }^{50} \mathrm{~A}$ condition may also be that the offender shall abstain from using alcohol or drugs, etc. In the latter case, he or she may also be tested for such substances.

The only measure that carries a trace of retribution is that the plan may state that the offender shall work for free for society. This clause is inspired by the rules concerning community sentences. ${ }^{51}$ There is an important difference, however: a community sentence is meted out by the court, and has to be between 30 and 420 hours. Thus, there is a limit to how many hours the offender may have to serve. In addition, two offenders receiving the same number of hours of community sentence will have a similar punishment (even though the correctional services may decide how much of the sentence which shall consist of work, how much of participating in programmes, etc.). The action plan is made after the court's judgement is final, and it will normally not be known to the public whether the offender has to work; neither will it be known to the public what the action plan will contain in terms of other measures. ${ }^{52}$

This way of dividing the kinds of measures is used in Holmboe 2016b pp. 131-132. Compare a similar rule in The Correctional Services Act 2001-05-18-21, section 53. See Fornes 2016 p. 263. See The Execution of Sentences Act, section 53. For a criticism of this rule and a suggested amendment of the law, see Holmboe, Ytring: Om 'samfunnsnyttige oppgaver' i ungdomsplaner. Behov for reform?, 16 Tidsskrift for strafferett (2016) pp. 3-7. 


\subsection{The Following Through of the Action Plan}

When an action plan is formed and signed, it has to be followed through. This responsibility belongs to a follow-up team. ${ }^{53}$ The team is chaired by the youth co-ordinator and consists of the offender and his or her guardian, and others who are responsible for parts of the following through of the action plan. The youth co-ordinator may also ask other people connected to the offender or to the case to take part on the team. Representatives from the correctional services and the police shall always be part of the team in cases concerning youth punishment.

The offender shall, of course, fulfil the measures in the action plan. There are also general requirements in the law: ${ }^{54}$ the offender shall meet punctually at the right place for the meetings. He or she shall not be under the influence of alcohol, drugs, etc. during such meetings. Neither shall he or she behave threateningly or negatively. He or she shall not commit new criminal acts during the follow-up period. He or she cannot travel out of Norway without the consent of the youth co-ordinator.

It is not stated in the Mediation Services Act that the offender is always forbidden to use alcohol, drugs, etc. (The use of drugs will in itself be a criminal offence, though.) Such a condition may, however, be stated in the action plan. If this is not done, the youth coordinator may forbid the offender to use alcohol, drugs, etc. if it is necessary to prevent a criminal offence that may threaten someone's life, health or freedom. In such a case, the youth co-ordinator may also be obliged to alert the police if he or she finds it likely that the offender may commit such a crime anyway. ${ }^{55} \mathrm{He}$ or she may also be obliged to alert the child welfare services if the offender is still less than 18 years of age and has shown persistent, serious behavioural problems. ${ }^{56}$

\section{Procedure When the Action Plan Is Not Fulfilled}

If the offender violates conditions stated in the action plan or other measures, he or she must meet with the youth co-ordinator who will underline the consequences of further violations. ${ }^{57}$ The youth co-ordinator may also lay down certain new obligations for the offender in order to avoid new violations. Such new conditions, however, must be accepted by the follow-up team, including the offender. This may seem a strange solution. Ideally,

53 See The Mediation Services Act, section 26.

$54 \quad$ See The Mediation Services Act, section 27.

55 See The Criminal Code, section 196, which overrides the obligation of confidentiality.

56 The Child Welfare Act 1992-07-17-100, section 6-4. See Holmboe, Tale eller tie: Om plikt til å avverge alvorlige lovbrudd og uriktige domfellelser (Gyldendal Juridisk 2017) p. 183.

$57 \quad$ See the Mediation Services Act, section 31. 
the offender should understand that it is wise to accept a new condition. For instance, he or she may have been using alcohol and thus not shown up at school or work, and the youth co-ordinator then wishes to lay down an obligation to abstain from alcohol. If the offender does not agree, the condition cannot be imposed. It could possibly be a better solution if the follow-up team could impose the new condition without the consent of the offender. Such a condition could then be appealed to a higher authority. Unfortunately, there is no authority to appeal to according to the present formulation of the act.

If the offender again violates the conditions, the youth co-ordinator may either call for a new youth conference (with the consent of the correctional services and the police), or transfer the case to the correctional services and recommend that the case be brought before the court. The court will then have to decide whether the alternative imprisonment shall be executed (wholly or in part). If the offender commits a new crime, the prosecution authority may bring the case before the court and ask the court to order that the alternative imprisonment shall be executed wholly or in part.

\section{Evaluation: Are the Rules Well Suited to Punishment and the Rule Of Law?}

\subsection{How Severe Is Youth Punishment Compared with a Community Sentence?}

The reasoning behind youth punishment is that it will often be better suited to the needs of a young offender than a community sentence will be. It is also held that youth punishment is more severe than a community sentence. In fact, this argument of the severity of the youth punishment seems to be used as a reason for reducing the use of imprisonment towards young offenders. Nevertheless, community sentences are still being used in several cases against young offenders. Youth punishment is only meant to replace the most severe community sentences.

When a young offender gets a community sentence instead of a youth punishment for serious crimes, the number of hours may easily gravitate towards the maximum of 420 hours. In recent years, the Norwegian Supreme Court has decided several cases where young offenders have been sentenced to community sentence. See, e.g., Rt. 2010 p. 1313 (offender 17 years old; robbery; 417 hours community sentence (the sentence reduced by three hours because of time spent in custody), two years six months' alternative sentence of imprisonment); Rt. 2011 p. 206 (offender 17 years old; deprivation of freedom and attempted aggravated robbery; 419 hours, alternative sentence one year and four months); Rt. 2013 p. 734 (offender 16 years old; sexual intercourse with two girls of respectively 13 and 12 years old; 420 hours community sentence, alternative sentence of imprisonment one year two months). 
The relationship between the community sentence and the youth punishment can be shown thus:

Table 1: Community sentence and youth punishment, compared

\begin{tabular}{|l|c|c|}
\hline & Community sentence & Youth punishment \\
\hline $\begin{array}{l}\text { May be combined } \\
\text { with prison sentence? }\end{array}$ & Up to 60 days' imprisonment & No \\
\hline $\begin{array}{l}\text { Subsidiary prison } \\
\text { sentence }\end{array}$ & Yes & Yes \\
\hline $\begin{array}{l}\text { Period for the } \\
\text { execution of the } \\
\text { sentence }\end{array}$ & $\begin{array}{c}\text { Normally not less than 120 } \\
\text { days }\end{array}$ & $\begin{array}{c}\text { From six months to two } \\
\text { years; three years in grave } \\
\text { circumstances }\end{array}$ \\
\hline $\begin{array}{l}\text { Number of hours the } \\
\text { offender will serve }\end{array}$ & 30 to 420 hours & $\begin{array}{c}\text { Not fixed in the sentence. } \\
\text { Defined in the youth } \\
\text { meeting }\end{array}$ \\
\hline
\end{tabular}

If a community sentence is combined with imprisonment, it is hardly fitting to say that the punishment is less severe than a youth punishment. ${ }^{58}$ However, even if the community sentence is not combined with a prison sentence, it is not obvious that a community sentence will seem less severe to the offender than a youth punishment. That will depend on the content of the action plan. In some cases, the youth punishment may be seen as quite severe. For instance, the plan may contain a duty to live in an institution, or a duty to perform unpaid work for the community. In other instances, the offender will not need heavy or long-term follow-up, even if the crime was serious. In such cases, a community sentence would be more severe. A possibility could be to amend the Act concerning youth punishments, so that the condition of unpaid work for the community could be decided by the court in sentencing, as this is the most retributive part of the punishment.

\subsection{The Requirement for Residence in Norway}

There may be good practical reasons for requiring the offender to live in Norway in order to be sentenced to youth punishment. Nevertheless, this begs the question as to whether young offenders not resident in Norway shall be treated more severely just because they are not resident here. The issue is not easy to solve satisfactorily, but should be addressed thoroughly by the legislator. 


\subsection{The Lack of the Possibility of Combining Punishments}

When the offender is tried for crimes committed both before and after he or she turned 18 , it would be an advantage if the court could mete out a punishment for the crimes committed after 18 in combination with a youth punishment. As the law is today, the court must either let a new crime hinder the use of youth punishment, or in practice not mete out any punishment for the new crime. A relatively small crime committed after the defendant turned 18 years old may bar the court from applying youth punishment even if such a punishment would be suitable and restorative for the more serious crime committed before. Alternatively, a crime committed after the defendant turned 18 years old may go unpunished. It could therefore be a better solution to amend the law so that certain combinations of punishments could be allowed.

\subsection{The Lack of Control in the Action Plan}

The offender can choose not to agree to an unreasonable proposal for a condition in the action plan. At first glance, it may thus seem that the offender is safe from being subject to unreasonable terms in the action plan. However, he or she declines proposed terms at a great risk, as imprisonment is a likely outcome if the case is returned to the court because no action plan is agreed upon. It is not possible to demand a review of proposed terms. In my view, there should be some way of administrative review before it is decided that a case shall be sent to court for execution of the alternative imprisonment. One possibility could be to create a complaints board. If the offender's complaint did not lead to an amendment in the action plan, he or she could then choose whether to accept the proposed action plan or not. This would make the process safer for the offender, but it could also be easier for him or her to accept the proposed plan if the terms were upheld after the review.

\subsection{The Offender's Duty to Accept the Facts in the Youth Meeting}

In an ideal youth conference, the offender accepts responsibility for his or her actions when meeting the victim and the conference fulfils the ideals of restorative justice. However, the offender knows that he or she has to 'accept responsibility' even though he or she does not truly mean it. This forced apology is hardly restorative. It would be more in line with the ideals of restorative justice if the offender could choose whether to talk about the case with the victim. If the law were amended in this way, the victim would also have better reason to trust that the offender's apology is sincere. This would give the victim and the offender a better opportunity to fulfil the aims of restorative justice. 


\subsection{The Court's Lack of Options After an Action Plan is Not Fulfilled}

In many cases where the court sentences a young offender to youth punishment, a community sentence would also be an option. However, when a case is returned to court because the action plan was not agreed to or fulfilled, it is debatable whether the court can convert the alternative prison sentence to a suspended sentence. The court cannot convert the youth punishment to a community sentence. It would be reasonable to give the judge the same freedom to choose the right form of punishment when the case is referred back to court as when the case was decided in the first place.

\section{Conclusion}

Youth punishment is a valuable addition to the Norwegian system of punishment. Nevertheless, there are certain quirks and unforeseen consequences of the system that may serve as a trap for the offender when he or she consents to this form of punishment. The law has now been in force for three years, and the time has come to look it over to ensure that the system works according to the intentions of the legislator. Thus, the youth punishment could be an even better opportunity for the offender and the victim than it is today. 